\title{
Evaluation of Pre-Service English Teachers' Integration of Educational Technology into their Lesson Plans
}

\author{
Sri Wahyuni \\ Universitas Negeri Semarang, Indonesia \\ sriwahyunifbs@mail.unnes.ac.id
}

Received: 20 December 2017. Revised: 5 February 2018. Accepted: 10 April 2018

\begin{abstract}
The emergence of technology has shifted so many aspects of people' lives including but not limited to the way they interact with each other and accomplish almost all activities. In education context, use of technology has impacted teachers and students' interactions both in and outside classroom. For decades now, there has been research on technology use and its' benefits on teachers' instructional practices and students' learning. However, a study specifically looking at the integration of technology into teachers' lesson plans is still under research. Therefore, the paper was an attempt to investigate how pre-service English teachers integrated technology in the preparation stage of the instructional activities. The study focused on the evaluation of 22pre-service English teachers' lesson plans. It employed a qualitative approach with a document review method. It revealed that the pre-service English teachers have incorporate deducational technology including mobile devices and digital recording. Besides, the most frequently and commonly digital media used were Power Points, audios, videos and online resources downloaded from YouTube. In addition, they made use of communication and collaborative resource such as blogs. Finally, implication for further research is presented
\end{abstract}

Key words: digital technology, lesson plan, English instruction, digital devices, social networking sites

How to Cite: Wahyuni, S. (2018). Evaluation of pre-service English teachers' integration of educational technology into their lesson plans. Language Circle: Journal of Language and Literature, 12(2), 227-234.

\section{INTRODUCTION}

Pervasive use of technology in EFL classrooms has apparently been acknowledged for its positive impacts. Seen from teachers' perspective, use of technology is "essential and should be a part of today's learning". Students also perceive that teacher's use of technology enhances students' interest and satisfaction in learning (Lea, Clayton, Draude, \& Barlow, 2001). In addition, it was claimed to enhance students' motivation and knowledge retention (Granito and Chernobilsky, 2012). Similarly, use of technology has helped improving classroom activities, motivate students, and engage them in classroom activities (Tabatabaei \& Gui, 2011). This is supported by Kasapoglu-Akyol (2010) summarizing that most students preferred the use of technology-computers in developing their second language skills. "Bilingual word processors are excellent way to further writing development and motivate students to write". This is in line with Nomass' 2013 study indicating that in general technology helped learners learn the language faster. Technology also supported the development of language skills such as listening, speaking, and writing as well as 
vocabulary. This is similar to Alsulami's 2016 finding that the integration of technology influenced reading and writing in many ways. It indicated that computer software, social networking websites, online videos, audio tools (YouTube, Sype, MP3players), and smart phones and tablet apps had positive impact on learning English as a foreign language. Palmer's 2012 study uncovered that blended learning so called iZone was effective and applicable for language learning in the now generation. Similar study by Tosun (2015) showed that blended learning could enhance students' vocabulary knowledge. In addition, Marchetti and Cullen (2014) examined students' preference for learning new language from image prompts. They found out that majority of students preferred to connect vocabulary to picture or image, or to a combination of text and image. Video and visual media made students easier to participate in speaking activities. In the classroom, they made use of the internet to look up unfamiliar words in dictionary and find out more information in relation to teachers' explanation. Outside classroom, social networking sites such as messenger, FaceBook, WhatsApp, E-mail, Skype, and Instagram facilitated them in enriching their language skills. A study carried out by Boche and Henning (2015) revealed that using film, optical illusions, graphics, non-fiction broadcasts, and other technological as well as multimodal resources may help students realize that meaning can be found and made in multiple places and multiple modes. On the part of the teachers, use of digital technology contributed to improve teachers' instructional practices. Tabatabaei \& Gui (2011) revealed that the advancement of technology allowed the teachers to be more creative in conducting instructional practices both online and offline.
In Indonesian educational context, use of technology for instructional purposes is supported by government policies and facilities. For example, in regard to the implementation of the 2013 curriculum in 2016 the Ministry of Education and Culture launched the Regulations on the National Standard of Education No. 20about graduate competence standard, No. 21 content standard, and No 22 process standard respectively. It is explicitly stated that learning outcomes of secondary education graduates is that students acquire factual, conceptual, procedural, and metacognitive knowledge related to science, technology, art, and culture. Meanwhile, in the process standard it is mentioned that ICT should be integratedly, systematically, and effectively implemented to facilitate students' learning. In order to facilitate students' learning and make classroom activities more effective, schools are supposed to carry out information communication technology (ICT)-based teaching and learning for certain school subjects. With this regulation in mind, some top schools both public and private equip themselves with laboratories of language, computer, and multimedia. The classes are provided with computers, projectors, active speakers, and internet connection which are easily accessible for the school society.

The 2013 curriculum for secondary education further states that the process standard consists of four processes, i.e. planning, implementation, evaluation, and supervision. In relation to the previous explanation of the student learning outcomes and instructional practices requiring the mastery and use of technology, therefore, it implies that technology is supposed to be incorporated in those four stages of the instructional practices. The planning stage requires teachers to prepare a set of teaching 
documents and one of them is a lesson plan. Lesson planning is considered as an important part of the whole instructional programs. Ashcraft (2014:1) claims that

"Lesson planning is at the heart of being an effective teacher. It is a creative process that allow us to synthesize our understanding of second language acquisition and language teaching pedagogy with our knowledge of our learners, the curriculum, and the teaching context. It is a time when we envision the learning we want to occur and analyse how all the pieces of the learning experience should fit together to make that vision a classroom reality."

Ashcraft (2014) further summarizes that there are some advantages of preparing a lesson plan before classroom practices. The benefits are: 1) Lesson planning produces more unified lesson (Jensen, 2001); 2) Lesson planning process allows teachers to evaluate their own knowledge with regards to the content to be taught (Reed \& Michaud, 2010); 3) Planning the lesson will make teachers more confident (Jensen, 2001); 4) Lesson plan is reusable (Jensen, 2001). It means that it will save time for future use (Ashcraft, 2014); 5) Lesson plan can be used by other teachers (Jensen, 2001); and 6) Lesson plan can show teachers' pedagogical competence. With this in mind, teachers' pedagogical competence in planning the lesson is central to effective and successful teaching. This is in line with the Regulation of National Education Ministry No. 16 year 2007 concerning with the academic qualification standard and teacher competencies. It states that one of the teachers' pedagogical competencies is to be able to make use of ICT for teaching and learning purposes.

Integration of technology into education practices is also believed to develop students' 21st century skills. Trilling and Fadel (2009:xxvi) categorize the 21st century skills into three: 1) Learning and innovation skills: Critical thinking and problem solving, Communications and collaboration, Creativity and innovation; 2) Digital literacy skills: Information literacy, Media literacy, Information and communication technologies (ICT) literacy; and 3) Career and life skills: Flexibility and adaptability, Initiative and self-direction, Social and cross-cultural interaction, Productivity and accountability, Leadership and responsibility. It indicates that educational technology employed now should prepare the Net generation to be able to cope with the future challenges.

A number of studies previously mentioned had been conducted to explore teachers and students' perception on the use of technology. Others have focused on investigating the benefits using technology in classroom practices. Notwithstanding, research specifically carrying out to see how the integration of technology into the lesson plans is not very much explored. Given these basis, this study was aimed at investigating pre-service English teachers' use of technology in their lesson plans. Therefore, this study would further explore the answers of the following questions: (1) What kinds of technology do pre-service English teachers integrate into their lesson plans? and (2) How are the choices of technology realized in the lesson plans?

\section{Methodology}

The current study belongs to a qualitative approach with a document review method. The Department of Health and Human Services (2009) states that "document review is a way of collecting data by reviewing existing documents". Similarly, WBI 
education group (2007) mentions that "document review is to review a variety of existing sources (documents, reports, data files, and other written artifacts) with the intention of collecting independently verifiable data and information". With these in mind, the data of the study were obtained from the lesson plans produced by the preservice English teachers of Universitas Negeri Semarang. The existing documents were soft and hard files collected from the library of the English Department, Universitas Negeri Semarang.

The pre-service English teachers involved in this study were those attending teacher training program - Pendidikan Profesi Guru (PPG) Sarjana Mendidik di Daerah Terdepan, Terluar, dan Tertinggal (SM3T) in the 2014-2015 academic year. They were English education graduates who attended ayear teacher training program - PPG SM3T. The program consisted of two main activities; workshop on the development of teaching documents and teaching practicum. They were 12 females and 8 males graduated from English Education Study Programs of different teacher education institutions in Central Java.

Lesson plans as data sources in this study were one of the teaching documents produced by pre-service English teachers PPG SM3Tof the English Education Study Program, Faculty of Languages and Arts, Universitas Negeri Semarang. The lesson plans were developed based on the template provided by the Regulation of Cultural and Educational Ministry No. 22 year 2016. This should contain of components including:1) School Identity; 2) Subject/Course; 3) Class/Semester; 4) Topic 5) Time allotment; 6) Core Competence; 7) Basic Competence and Competence Achievement Indicators; 8) Instructional Objectives; 9) Instructional materials; 10) Instructional Techniques; 11) Instructional Media; 12) Instructional sources; 13) Instructional stages - Opening - Core Closing; and 14) Assessment.

The document review followed procedures: 1) access existing documents; 2) compile the documents relevant to the study; 3 ) understand how and why the documents were produced; 4) determine the accuracy of the documents; and 5) summarize the information which is the research data from documents reviewed; and 6) coding and classifying the obtained data. In regard to the current study, the data later were analyzed and confirmed with the categorization of digital technology by $\mathrm{Ng}$ (2015).

The present study was only limited to the scope of exploring educational technology integrated into the lesson plans. Discussion other than this specific topic such as whether or not the planned-document was implemented in real classroom instruction would not be covered in this paper.

\section{Findings and Discussion}

As previously mentioned, the current study was a document review which aimed to evaluate the existing lesson plans. Each lesson plan was designed for the eighth grade students of secondary education with 80minute time allotment. The evaluation focused on the incorporation of educational technology in the lesson plans. The technology as used in the study referred to digital and mobile devices, online resources, social media, Web 2.0 technology, communication and collaborative resources, and education software application $(\mathrm{Ng}$, 2015).

The findings revealed that there was a number of digital technology choices made by the pre-service teachers. Most of them mentioned the use of mobile devices such as 
laptops, notebooks and audio-video recorder. Besides, they used electronic equipment including LCD projectors and active speakers. They also took benefits of digital media such as Power Point slides, audios, and videos. Communication and collaborative resources such as blogs were also included. In addition, the most commonly used social networking site was YouTube. In addition, they made use of other online resources such as software application for e-dictionary and links for online English learning. For more detailed data, the following charts 1 and 2 presents the participants' choices of digital devices, media, and other electronic equipment.

\section{Participants' Use of Digital Devices and Electronic Tools}

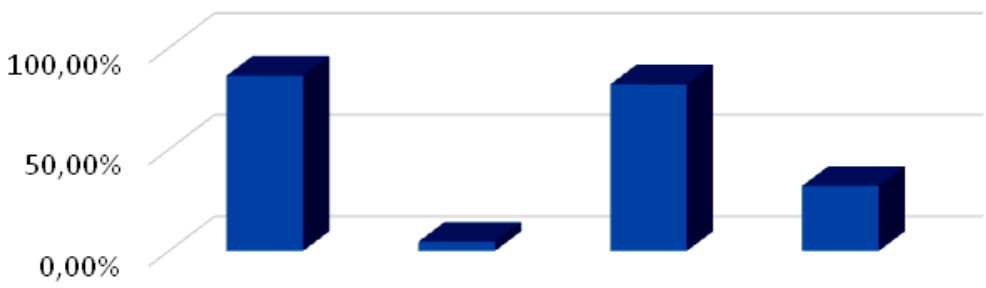

Laptops Audio-video recordeid projectors Active speaker

\section{Chart 1 Participants' Use of Digital Devices and Electronic Tools}

Based on the chart 1 the most popular digital devices integrated into the lesson plans were laptops and LCD projectors. The choices of digital technology integrated into the lesson plans might be affected by several possible factors. First, it might be in accordance with the campus' facilities. The designed lesson plan later would be used as guidelines for peer teaching practice and the activity would be done in the classroom with limited facilities such as LCD projectors and active speakers. The pre-service teachers, therefore, would bring along their own personal laptops. The second possibility was that they considered about the schools' facilities they would be placed at to carry out the teaching practicum the following semester. They could be placed in schools with complete digital technology facilities or with less digital infrastructure or even without them at all. Besides, the lesson plan they designed in this course would likely be a model used in the future. As suggested by Jensen (2001) in Ashcraft (2014) that lesson plan can be reused in the future so that it can save time and energy. Third, another possibility was that it dealt with their digital and technology literacy. Due to their limited knowledge and skill to operate digital devices and search for the digital media, therefore, they made the choices. Besides, they made use of blog sites designed by mostly nonnative speakers of English. This choice of blog sites as one of the learning sources might be affected by the appropriateness of the content. The blog makers and owners design the sites and fill in the content in accordance with teachers' needs. However, in English language teaching context, it is important to provide authentic environment. It implies that 
authentic material is essential to facilitate students with real context of the language use. As suggested by Tabatabaei \& Gui (2011) that when learning a foreign language, it is important to provide a foreign country context. Accordingly, technology can be one of the alternatives. It is further argued that enhancing students' language can be optimized through authentic communication (Li \& Zou, 2017).

\section{Participants' Use of Digital Leaming Media and Sources}

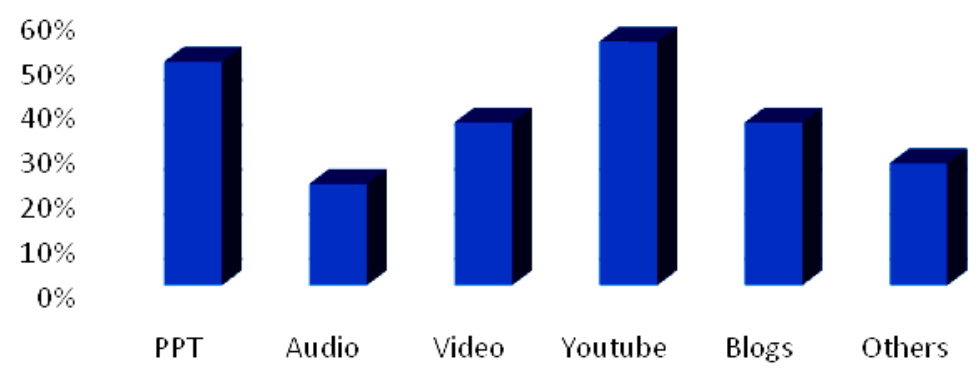

Chart 2 Participants' Use of Digital Learning Media and Sources

The chart 2 shows that the most to the least frequently and commonly used digital media were PPT, Videos and Audios. Meanwhile, it seems that YouTube was the most popular social networking site downloaded. Besides, they seemed dependent on the use of blog by non-native speakers of English.

The choices of instructional media and sources might be affected by the facts that those links are basic ones which can be made and used very easily. However, if they are well-implemented in classroom practices, they will support students' English learning. Marchetti and Cullen (2014) claimed that videos and visuals make students easier to participate in speaking activities in class. Social networking sites such YouTube and Blog are also very popular among students. Survey conducted by Wahyuni (2018) revealed that students were active users of social networking sites such as Facebook, WhatsApp, Line, Twitter, E-mail, Blog, Instagram, Messenger, and YouTube. They used social media more for exchanging information, communication, entertainment and other private needs than for learning purposes. With this situation in mind, use of social networking sites should be maximized with regard to its' benefits in enhancing students' language skills. This in line with Alsulami's (2016) finding that the integration of technology helped to increase students' English skills. For examples, online video and audio tools including YouTube, Skype, MP3 Players could enhance students' listening and speaking skills. Social networking websites such as Facebook, twitter, WhatsApp, and blogs could develop their communication and reading and writing skills. With this in mind, thus pre-service English teachers might explore more types of digital technology 
which can be incorporated into the instructional documents. The lesson plans supported by the use of technology would likely be facilitating both teachers and students' classroom activities. It they are taken optimally, therefore, they would help teachers to develop their pedagogical competence. Besides, students would also be more engaged in the classroom and enhance their learning and motivation which finally results in obtaining better achievement and longer knowledge retention.

The choices of the educational technology including laptops, audio video recorders, LCD projectors, and speakers could be found in the 'instructional media and equipment' section of the lesson plan. In this section they promised to make use of those devices. Meanwhile, the use of digital media (i.e. PPT, Videos and Audios), social networking sites (YouTube), Education Software Packages (i.e. Cambridge Advance Learner's Dictionary, www.belajaringgris.net, etc.), as well as communication and collaborative resources (i.e. blogs) was realized in the 'instructional sources', 'instructional materials', 'learning stages', and 'instructional media' sections of the lesson plans. The participants also undertook the use of audio and video media in the 'assessment' section. The media completed with the transcripts was prepared for listening and speaking assessment.

\section{Conclusions and Implication}

To summarize, the pre-service English teachers involved in this study have incorporated a number of educational technology into their lesson plans as supporting tools in delivering the instructional materials and administering the assessment.
Besides, they have also used some electronic media-based such as PPT slides, audios and videos to support the instructional activities. Learning sources such as social media YouTube and Blogs were also taken as complementary materials to the textbooks.

With the findings in mind, it is advisable that the pre-service English teachers should develop their digital and technology literacy. In regard to the $21^{\text {st }}$ century skills, both teachers and students should be wellliterate in many aspects including digital, technology, internet, information, communication (Pletka, 2007). Besides, the institution should take this into consideration in developing the curriculum. The existing ICT in Language Learning course offered to the sixth semester students of English Education Study Program has been very rich in providing students with theories of ICTbased English instructions. However, content course in relation to practices in using the Web 2.0 technology and other online resources as well as educational software packages needs to be taken into consideration.

This finding suggests further studies on the technology use in EFL in Indonesian context which explore topics including 1) Reasons for making the choices referring to the findings of the current study that make up teachers and students' attitude towards technology; 2) Implementation of technology in the instructional processes, seeing whether the classroom practice reflects the predesigned lesson plans; 3) Teachers' readiness in integrating technology into EFL classroom, seeing what supports and inhibits the integration; and 4) Teachers' and students' awareness technology benefits in supporting instructional practices. 


\section{References}

Alsulami, S. (2016). The Effects of technology on learning English as a foreign language among female EFL students at Effatt College: An Exploratory Study. Studies in Literature and Language, 12(4), 1-16. DOI: http://dx.doi.org/10.3968/7926.

Ashcraft, N. (2014). Lesson Planning. Virginia: TESOL Press.

Boche, B. and Henning, M. (2015). Multimodal Scaffolding in the secondary English classroom curriculum. Journal of Adolescent and Adult Literacy, 58(7), 579-590. DOI: 10.1002/jaal.406

Department of Health and Human Services. (2009). Data Collection Methods for Evaluation: Document Review. $\quad$ https://www.cdc.gov/healthyyouth/evaluation/pdf/brief18.pdf. Accessed 5 January 2018

Granito, M. \&Chernobilsky, E. (2012). The Effect of Technology on a Student's Motivation and Knowledge Retention. NERA Proceeding Conference 2012.17. http://digitalcommons.uconn.edu/nera_2012/17. Accessed17 September 2017.

Kasapoglu-Akyol, P. (2010). Using educational technology tools to improve language and communication skills of ESL students. Research on Youth and Language, 4(2), 225-241. http://www.dphu.org/uploads/attachements/books/books_4761_0.pdf. Accessed 20 December 2017.

Kementerian Pendidikan Nasional. (2007). Permendiknas No. 16 tahun 2007 tentang Standar Kualifikasi Akademik dan Kompetensi Guru. Jakarta: Kemdiknas.

Kementerian Pendidikan dan Kebudayaan. (2016). Permendikbud No. 20 tahun 2016 tentang Standar Kompetensi Lulusan. Jakarta: Kemendikbud.

Kementerian Pendidikan dan Kebudayaan. (2016). Permendikbud No. 21 tahun 2016 tentang Standar Isi. Jakarta: Kemendikbud.

Kementerian Pendidikan dan Kebudayaan. (2016). Permendikbud No. 22 tahun 2016 tentang Standar Proses. Jakarta: Kemendikbud.

Lea, L., Clayton, M., Draude, B. \& Barlow, S. (2001). The Impact of Technology on Teaching and Learning. Educause Quarterly. 2 (2001) Retrieved from https://er.educause.edu/ /media/files/articles/2001/6/eqm0127.pdf?la=en.

Li, W. \& Zou, W. (2017). A Study of EFL Teacher Expertise in Lesson Planning. Teaching and Teacher Education. 66(2017), 231-241. https://doi.org/10.1016/j.tate.2017.04.009.

Marchetti, L. \& Cullen, P. (2016). A multimodal approach in the classroom for creative learning and teaching. Psychological and creative approaches to language teaching. pp. 39-51. https://www.cjv.muni.cz/cs/wp-content/uploads/sites/2/2016/02/cr-11516-marchetti.pdf.

Accessed 25 December 2017

Nomass, B. B. (2013). The impact of using technology in teaching English as a second language. English Language and Literature Studies, 3(1). Doi: 10.5539/ells.v3n1p111. http://dx.doi.org/10.5539/ells.v3n1p111.

Ng, Wan. (2015). New Digital Technology in Education: Conceptualizing Professional Learning for Educators. (eBook). DOI 10.1007/978-3-319-05822-1. Springer. 
Palmer, R. (2012). A Third Way: Online Labs Integrated with Print Materials. Indonesian Journal of Applied Linguistics, 2(1),1-9. Retrieved from http:// http://file.upi.edu/Direktori/FPBS/JUR._PEND._BAHASA_INGGRIS/196706091994031DIDI_SUKYADI/IJAL\%20January\%202013.pdf. Accessed 5 December 2017.

Pletka, B. (2007). Educating the Net Generation: How to Engage Students in the 21st Century. Santa Monica: Santa Monica Press LLC.

Tabatabaei, M.\& Gui, Y. (2011). The Impact of technology on teaching and learning languages. http://formatex.info/ict/book/513-517.pdf. Accessed 16 September 2017.

Tosun, S. (2015). The effect of blended learning on EFL students' vocabulary enhancement. Procedia - Social and Behavioral Sciences, 199 (2015), 641 - 647. http://www.sciencedirect.com/science/article/pii/S187704281504611X. Accessed 16 September 2017.

Trilling, B, \& Fadel, C.(2009). 21st Century Skills: Learning for Life in our Times. San Fransico: Jossey-Bass.

WBI Education Group. (2007). Document Review. siteresources.worldbank.org/WBI/ Resources/213798.../11Final-Document_Review.pd.. Accessed 5 January 2018

Wahyuni, S. (2018). Teachers and Students' Use of Digital Technology: Is It an Opportunity?. Proceedings: The $1^{\text {st }}$ JHS-ETA Semarang Regency International Conference on Integrating Technology in Language Classroom: A Revolution of $21^{\text {st }}$ Century Learning. Semarang: MGMP Bahasa Inggris SMP Kabupaten Semarang Jawa Tengah. 